\title{
Kuznets Prize for Richard W. Evans, Yingyao Hu, and Zhong Zhao
}

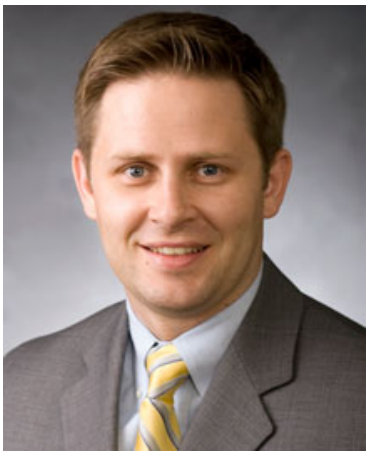

Richard W. Evans

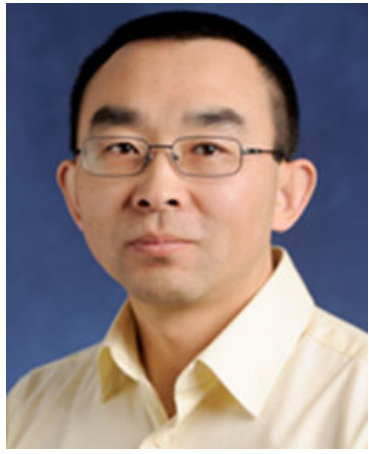

Yingyao $\mathrm{Hu}$

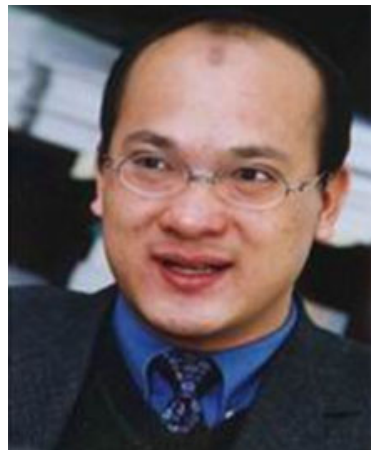

Zhong Zhao

Richard W. Evans, Yingyao $\mathrm{Hu}$, and Zhong Zhao received the Kuznets Prize for their article "The fertility effect of catastrophe: US hurricane births," Journal of Population Economics (2010), 23 (1):1-36. This prize honors the best article published in the Journal of Population Economics during the period 2010-2012.

\section{Biographical abstracts}

Richard W. Evans is an assistant professor of economics at Brigham Young University, specializing in international macroeconomics, monetary economics, public economics, and computational economics. Rick is the cofounder and codirector of the BYU Macroeconomics and Computational Laboratory and is one of the nine members of the Utah Economic Council. After receiving a B.A. in Economics from Brigham Young University in 1998, he began his economic career as a research 
economist at Thredgold Economic Associates in Salt Lake City, providing state and national economic analysis for Zions Bank and their operations in eight western states. Rick later received a M.A. in Public Policy from Brigham Young University and Ph.D. in Economics from the University of Texas at Austin. He has also spent time as a researcher at the Joint Economic Committee of the US Congress and the Federal Reserve Bank of Dallas and as an economic consultant.

Yingyao $\mathrm{Hu}$ is an associate professor at the Johns Hopkins University, where he received his Ph.D. in 2003. He is an associate editor of the Journal of Econometrics and Frontiers of Economics in China and was a panelist of the National Science Foundation in 2011. His research focuses on topics in micro-econometrics and its applications in industrial organization and labor economics. His research has been published in scholarly journals such as the American Economic Review, Econometrica, the Journal of the American Statistical Association, and the Journal of Econometrics.

Zhong Zhao is a professor of economics at the School of Labor and Human Resources, Renmin University of China and a research fellow of the Institute for the Study of Labor (IZA) in Bonn, Germany. He also held faculty position at Peking University, was a visiting assistant professor at the University of Southern California, and a visiting scholar at the Tinbergen Institute, University of Nottingham, University of Canberra, and the Johns Hopkins University. He holds a doctorate degree in economics from the Johns Hopkins University. His main areas of interest are labor economics, applied micro-econometrics, social program evaluation, and economy of China, among others. He has published in both international and Chinese economics journals such as Review of Economics and Statistics, Review of Income and Wealth, Journal of the Royal Statistical Society (Series A), Economics Letters, Journal of Population Economics, and China Economic Quarterly.

\section{About the Kuznets Prize}

The Journal of Population Economics awards the "Kuznets Prize" for the best paper published in the Journal of Population Economics during a 3-year period. Papers are judged by the editors of the Journal of Population Economics.

Simon Kuznets, a pioneer in population economics, professor emeritus at Harvard University, and the 1971 Nobel Prize laureate in economics, died on July 10, 1985. Professor Kuznets was born 1901 in Kharkov, Russia and came to the USA in 1922. He earned his Bachelor of Science in 1923, a Master of Arts degree in 1924, and his doctorate in 1926, all from Columbia University. During World War II, he was the associate director of the Bureau of Planning and Statistics on the War Production Board and he served on the staff of the National Bureau of Economic Research from 1927 to 1960 . Mr. Kuznets was a faculty member at the University of Pennsylvania for 24 years and a professor of political economy at Johns Hopkins University from 1954 until he joined Harvard University in 1960. He retired in 1971 and was given the title of George F. Baker Professor Emeritus of Economics. He was a former president of the American Economic Association and the American Statistical Association. 


\section{Previous Prize winners}

The Kuznets Prize has previously been awarded to:

Period 1995-1997: James R. Walker (University of Wisconsin-Madison), for his article "The effect of public policies on recent Swedish fertility behavior," Journal of Population Economics, 8:223-251

Period 1998-2000: David C. Ribar (The George Washington University), for his article "The socioeconomic consequences of young women's childbearing: Reconciling disparate evidence," Journal of Population Economics 12:547-565

Period 2001-2003: Olympia Bover (Bank of Spain) and Manuel Arellano (CEMFI), for their article "Learning about migration decisions from the migrants: Using complementary datasets to model intra-regional migrations in Spain," Journal of Population Economics 15:357-380

Period 2004-2006: Jinyoung Kim (Korea University) received the Kuznets Prize for his article "Sex selection and fertility in a dynamic model of conception and abortion," Journal of Population Economics 18: 041-067

Period 2007-2009: Makoto Hirazawa (Nagoya University) and Akira Yakita (Nagoya University) for their article "Fertility, child care outside the home, and pay-as-you-go social security," Journal of Population Economics 22:565-583. 